\title{
Agricultural Researchers' Awareness of the Causes and Effects of Climate Change in Edo State, Nigeria
}

\author{
T. O. A. Banmeke (Corresponding author), E. O. Fakoya \& I. F. Ayanda \\ Department of Agricultural Extension and Rural Development \\ University of Agriculture, P.M.B. 2240, Abeokuta, Nigeria \\ Tel: 234-805-530-9320_E-mail: tajudeenbanms@yahoo.com
}

\author{
Received: April 12, 2011 \\ Accepted: April 30, $2011 \quad$ Online Published: December 1, 2011 \\ doi:10.5539/jas.v4n1p233 \\ URL: http://dx.doi.org/10.5539/jas.v4n1p233
}

\begin{abstract}
The study assessed Agricultural researchers' awareness of the causes and effects of climate change in Edo State, Nigeria. Data for the study were collected from 112 respondents and were analyzed using descriptive and inferential statistics. Findings indicated that $45.5 \%$ of the respondents were between the ages of 31-50 years with $64.2 \%$ having a work experience of 5-10 years. Results revealed that $96.4 \%$ and $94.6 \%$ of the respondents were aware of gas flaring and oil spillage as causes of climate change. Also, $98.2 \%$ and $95.5 \%$ of the respondents were aware of increase in temperature and change in rainfall pattern respectively as some of the effects of climate change. There was a significant relationship between information sources and awareness of causes of climate change $(r=0.32 ; p<0.05)$. It was recommended that agricultural researcher should be pragmatic and proactive in the pursuit of issues relating to climate change.
\end{abstract}

Keywords: Climate change, Researcher, Awareness, Effects

\section{Introduction}

Nigeria apart from being a major oil exporter has an agrarian economy that is predominantly dominated by small scale farmers. Apart from majority of the farmers being small-scaled, agricultural practices in the country is tied to climatic conditions such as rainfall to water their crops, sunlight for drying their farm produce amongst others. Also, climatic factors such as temperature, rainfall and wind are essential in crop growth, development, storage and these factors also set a limit to livestock productions. It therefore becomes imperative to note that climate change and agricultural processes are interrelated, since all the stages involved in agricultural production such as sowing, crop growth and development, storage and others are dependent on climate (Ayoade, 2004). Owing to the dependence of the country's agricultural system on climate and environmental factors, agricultural practices are continuously faced and prone to natural disasters (Rahimi, 2000).

Intergovernmental Panel on Climate Change (IPCC,2001) define climate change as a statistically significant variation that persist for decades or longer caused by human and non-human activities. Some human causes include deforestation, oil spills and gas flaring, while some non-human causes include volcanic eruptions and ocean current.

It is in this regard that Gwary (2008) posited that the negative consequences of climate change may result in 50\% decline in livestock and crop production. In collaborating this assertion Food and Agriculture Organisation (FOA, 1997) had posited that agricultural production will be affected by these climate change related drivers, i.e. temperature, precipitation, sea level rise and atmospheric carbon dioxide content with attendant reduction in crop yield and agricultural productivity. Climatic conditions therefore poses a lot of scientific challenges to researchers from all over the world especially in developing countries coupled with the change in climatic conditions, which must be tackled with new ideas, reliable data and advanced instrument. Spore (2008) asserted that climate change is making crop scientist to redirect their research effort by not only trying to develop improved and high yielding varieties of crops but also developing stress-tolerant varieties to cope with the challenges posed by this phenomenon.

It therefore becomes imperative that agricultural researchers that have the responsibilities of generating innovations in agriculture are aware of the causes and effects of climate change which would assist them in meeting those challenges posed by the effects of climate change. 


\section{Objective of the study}

The general objective of the study was to examine agricultural researchers' awareness of climate change issues in Edo State Nigeria. The specific objectives were to:

1) Describe the personal characteristics of agricultural researchers in Edo State

2) Identify the sources of information on climate change issues to the respondents.

3) Examine agricultural researchers' awareness of the causes of climate change in the study area.

4) Determine agricultural researchers' awareness of the effects of climate change in the study area.

\section{Hypotheses of the study}

The hypotheses of the study are stated in the null form that:

1) "There is no significant relationship between the personal characteristics of the researchers and their awareness of the effects of climate change"

2) "There is no significant relationship between the sources of information and awareness of the effects of climate change".

\section{Methodology}

This study was conducted in Edo State of Nigeria between June and October 2009. Edo State is an inland state in Central Southern Nigeria with its capital in Benin City. The state is bounded in the North and East by Kogi State, in the South by Delta State and in the West by Ondo State. Edo State is at an elevation of between $150 \mathrm{~m}$ above sea level in the South and more than $550 \mathrm{~m}$ above sea level in the North. The vegetative cover is the tropical rain forest that covers most part of the state with a land area of about 17,802 km. Some of the major cash crops produced are rubber, cocoa, and palm produce. In addition, crops such as cassava, yams, plantain, and assorted types of fruits and vegetables are also produced.

There are two public universities in the state, which are the University of Benin, Benin City (UNIBEN) and Ambrose Ali University, Ekpoma (AAU), and two agricultural research institutes, which are the Nigeria Institute for Oil palm Research (NIFOR) and Rubber Research Institute of Nigeria (RRIN). All of these institutions were used for this study. Furthermore, the faculties of Agriculture in the two universities were purposively chosen. A simple random sampling method was used to select $50 \%$ of researchers from the two faculties of Agriculture and research institutes for the study. Therefore a total of 40 researchers were sampled from NIFOR, 26 from UNIBEN, 24 from RRIN and 22 from AAU. This gave a total of 112 researchers that were sampled for this study. Data for the study were gathered through the use of a structured questionnaire that was content analysed by professionals in the field of agricultural communication.

Researcher's source of information on climate change issue was ascertained by using a four point rating scale of regularly (4 points) occasionally ( 3 points), rarely ( 2 points) and never ( 1 point) on a list of sources such as internet, journals, fellow researcher, newspaper/magazine, radio, and T.V. The researcher's awareness of climate change issues was ascertained by asking weather they are aware or not aware of the causes and effects of climate change. Some of the causes enumerated were gas flaring, oil spillage, deforestation, fermentation of cattle dung, and some effects of climate change enumerated were change in rainfall pattern, increased sea level, increased temperature and decrease in crop yield.

The data for this study were analyzed using descriptive statistics such as frequency counts, percentage, mean and standard deviation, while Chi-square and Pearson Product Moment Correlation were used to draw inferences.

\section{Results and Discussion}

\subsection{Personal characteristics of respondents}

The personal characteristics of the respondents are presented in Table 1. Results reveal that $82.1 \%$ of the respondents are male, while $17.9 \%$ are female. This shows that there are more male researchers than female researchers in faculties of Agriculture in the universities and agricultural research institutes in the study area. This is similar to the pattern reported by Oloruntoba and Ajayi (2006) that only $10 \%$ of university teachers in Nigeria are females. Table 1 also indicates that $45.5 \%$ of the respondents are within the age bracket of 31-40 years, which is an indication that many of the researchers are young. Also, $80.4 \%$ of the respondents are married which is expected because most of them are within the age bracket that marriage is considered important in this part of the world. Furthermore, $93.7 \%$ of the researchers are Christians which may be adduced to the fact that Christianity is the predominant religion in this part of the country. Results in Table 1 also reveal that $54.5 \%$ of the researchers are M.Sc. degree holder which may be attributed to the fact that a M.Sc. degree is a requirement 
for entry into universities and research institutes. Findings further reveals that $64.2 \%$ of the researchers have between 5-10 years working experience. This indicates that most of the researchers are relatively experienced on the job and should therefore be familiar with the workings of their organization.

Furthermore, $26.8 \%$ of the respondents specialized in crop science and this may be due to the fact that most of the research institutes are crop biased.

\subsection{Respondent's sources of information on climate change}

Respondent's sources of information on climate change are presented in Table 2. The result shows that all the sources listed are important sources from which respondents obtain information on climate change since their means were greater than 2.50. However, the major sources as indicated by the respondents are internet $(x=3.55)$, Television $(x=3.44)$, Journals $(x=3.22)$ and newspapers/magazines $(x=3.30)$. This is not surprising because the internet is now an important means through which many enlightened individuals obtain information. Banmeke (2007) similarly reported that the internet is used for various activities among students in the Faculty of Agriculture, University of Benin, Benin City.

\subsection{Respondents' awareness of the causes of climate change}

Respondents' awareness of the causes of climate change presented in Table 3 indicates that $96.4 \%$ of the respondents are aware of gas flaring, 94.6\% of the respondents are aware of oil spillage, 93.8\% are aware of deforestation and $92.9 \%$ are aware of fossil fuel burning as some of the causes of climate change. Furthermore, $48.2 \%$ and $28.6 \%$ of the respondents noted that they are not aware of fermentation of cattle dung and inorganic fertilizer as causes of climate change respectively. This indicates that most of the respondents in the study area are quite aware of the different causes of climate change. This is expected as most of them are well educated as indicated in Table 1 and probably due to the fact that the study area is located in the Niger delta and issues around oil exploration is of major concern.

\subsection{Respondents' awareness of the effects of climate change}

Respondents' awareness of the effects of climate change in Table 4 indicates that $98.2 \%$ of the respondents are aware that increase in temperature is one of the effects of climate change. Also, 95.5\% and $91.1 \%$ are aware of change in rainfall pattern, decrease in crop yield and increased production cost as some of the effects of climate change. This indicates a high level of awareness of the effects of climate change by the respondents of the study. This is expected because as indicated in Table 3 above that most of the respondents are aware of the causes of climate change.

\subsection{Relationship between respondents' personal characteristic and their awareness of the causes and effects of climate change}

Tables 5 and 6 show the relationships between respondents' personal characteristics and their awareness of the causes and effects of climate change. There are significant relationships between respondents areas of specialization and awareness of the causes $\left(\chi^{2}=10.50 ; p<0.05\right)$ and effects of climate change $\left(\chi^{2}=12.40 ; p<\right.$ 0.05). This result is not unexpected because respondent's area of specialization will arouse their interest in climate change issues.

\subsection{Relationship between information sources and awareness of the causes and effect of climate change}

The relationship between respondent's sources of information and awareness of the causes and effect of climate change is presented in Table 7. Results indicate that there is a significant relationship between information sources and awareness of causes of climate change $(\mathrm{r}=0.32 ; \mathrm{p}<0.05)$. This is expected because the information sources will affect the type of information the respondents will be accessible to.

\section{Conclusion and recommendations}

It is obvious from the study that the important sources of information on climate change issues are internet, television and journals. Also, many of the researchers are aware of gas flaring, oil spillage and deforestation as some of the causes of climate change, the major effects of climate change the respondents are aware of are increase in temperature, change in rainfall pattern and decrease in crop yield. There is a positive and significant relationship between respondents' sources of information and awareness of the causes of climate change. From the foregoing it is therefore recommended that agricultural researcher's access to the internet be improved on as it will not only facilitate their work, but at the same time keep them abreast of happenings in the international scene. Researcher's interest in climate change issues should also be sustained by organizing workshops and seminars on the issue. 


\section{References}

Ayoade, J. O. (2004). Introduction to Climatology for the Tropics, Spectrum books, Ibadan, pp:297.

Banmeke, T.O.A. (2007). Internet use by students in selected departments of the faculty of Agriculture, University of Benin, Benin City, Nigeria, Journal of Agriculture, Forestry and the Social Sciences, 5(1): 29-36.

Food and Agriculture Organisation (FAO). (1997). Agriculture and climate change: FAO's role on climate change and likely impact on Agricultural sector. [Online] Available: http://www.fao.org/ag/agns/fills/HLC_climatechange_and_foods_safety.pdf (February 10,2007.)

Gwary, D. (2008). Climate change, food security and Nigeria's agriculture. A paper presented at the ministry of agriculture. [Online] Available: http://www.guardiannews.com (July 15, 2009).

Intergovernmental panel on climate change (IPCC). (2001). Mitigation and adaptation strategies of climate change: Summary for policy makers. [Online] Available: http://www.IPCC (October 5, 2009).

Oloruntoba, A. and Ajayi, M.T. (2006). Gender and research attainment of academics in Nigerian Agricultural Universities, Journal of Higher Education in Africa, CODESRIA, 4(2): 83-98.

Rahimi, E. (2000). Policies for supporting farmers: A case study for research center for rural study. Ministry of Agriculture Abuja, pp. 215.

Spore. (2008). Climate change, special issue, Technical Centre for Agricultural and Rural Cooperation (CTA), Netherlands.

Table 1. Respondents' Personal Characteristics

\begin{tabular}{|c|c|c|c|}
\hline Variable & Categories & Frequency & Percentage \\
\hline \multirow[t]{3}{*}{ Gender } & Female & 20 & 17.9 \\
\hline & Male & 92 & 82.1 \\
\hline & Total & 112 & 100.0 \\
\hline \multirow[t]{5}{*}{ Age (Years) } & $20-30$ & 18 & 16.1 \\
\hline & $31-40$ & 51 & 45.5 \\
\hline & $41-50$ & 40 & 35.7 \\
\hline & Above 50 & 3 & 2.7 \\
\hline & Total & 112 & 100.0 \\
\hline \multirow[t]{3}{*}{ Marital status } & Single & 22 & 19.6 \\
\hline & Married & 90 & 80.4 \\
\hline & Total & 112 & 100.0 \\
\hline \multirow[t]{3}{*}{ Religion } & Christianity & 105 & 93.7 \\
\hline & Islam & 7 & 6.3 \\
\hline & Total & 112 & 100.0 \\
\hline \multirow[t]{5}{*}{ Education } & B.Sc. & 21 & 18.8 \\
\hline & M.Sc. & 61 & 54.5 \\
\hline & PhD. & 23 & 20.5 \\
\hline & Others & 7 & 6.3 \\
\hline & Total & 112 & 100.0 \\
\hline \multirow[t]{5}{*}{ Working experience (Years) } & $5-10$ & 72 & 64.3 \\
\hline & $11-15$ & 25 & 22.3 \\
\hline & $16-20$ & 11 & 9.98 \\
\hline & $>20$ & 4 & 3.6 \\
\hline & Total & 112 & 100.0 \\
\hline \multirow[t]{6}{*}{ Areas of specialization } & Crops science & 30 & 26.8 \\
\hline & Agric Econs./Ext. & 18 & 16.1 \\
\hline & Soil science & 15 & 13.4 \\
\hline & Forestry \& Wildlife & 6 & 5.4 \\
\hline & Others & 43 & 38.4 \\
\hline & Total & 112 & 100.0 \\
\hline
\end{tabular}

Source: Field Survey, 2009. 
Table 2. Respondent's sources of information on climate change

\begin{tabular}{|l|l|l|}
\hline Sources of information & Mean & Standard deviation \\
\hline Internet & $3.55^{*}$ & 0.682 \\
\hline T.V & $3.44^{*}$ & 0.641 \\
\hline Journal & $3.32^{*}$ & 0.661 \\
\hline Newspapers/Magazine & $3.30^{*}$ & 0.627 \\
\hline Fellow researcher & $3.10^{*}$ & 0.782 \\
\hline Workshop/reference & $3.08^{*}$ & 0.761 \\
\hline Radio & $2.98^{*}$ & 0.723 \\
\hline
\end{tabular}

* Mean is more than 2.50 and therefore important. Scale: Regularly $=4$ points, occasionally $=3$ points, rarely $=$ 2 points, never $=1$ point

Source: Field survey, 2009

Table 3. Respondents' Awareness of the causes of climate change

\begin{tabular}{|l|l|l|l|l|}
\hline Causes of climate change & \multicolumn{2}{|l|}{ Not aware } & Aware \\
\hline & Frequency & Percentage & Frequency & Percentage \\
\hline Gas flaring & 4 & 3.6 & 108 & 96.4 \\
\hline Oil spillage & 6 & 5.4 & 106 & 94.6 \\
\hline Deforestation & 7 & 6.3 & 105 & 93.8 \\
\hline Fossil fuel burning & 8 & 7.1 & 104 & 92.9 \\
\hline Green house gas emission & 11 & 9.8 & 101 & 90.2 \\
\hline Increased population & 18 & 16.1 & 94 & 83.9 \\
\hline Inorganic fertilizer & 32 & 28.6 & 80 & 71.5 \\
\hline Fermentation of cattle dung & 54 & 48.2 & 58 & 51.8 \\
\hline
\end{tabular}

Source: Field Survey, 2009.

Table 4. Respondents' awareness of the effects of climate change

\begin{tabular}{|l|l|l|l|l|}
\hline \multirow{2}{*}{ Effects of climate change } & \multicolumn{2}{l|}{ Not aware } & Aware \\
\cline { 2 - 5 } & Frequency & Percentage & Frequency & Percentage \\
\hline Increase in temperature & 2 & 1.8 & 110 & 98.2 \\
\hline Change in rainfall pattern & 5 & 4.5 & 107 & 95.5 \\
\hline Decrease in crop yield & 10 & 8.9 & 102 & 91.1 \\
\hline Increased production cost & 9 & 8.1 & 102 & 91.9 \\
\hline Flooding & 11 & 9.8 & 101 & 90.2 \\
\hline Reduced natural vegetation & 11 & 9.8 & 101 & 90.2 \\
\hline Increase in seal level & 13 & 11.6 & 99 & 88.4 \\
\hline Acid rain & 19 & 17.0 & 93 & 93.0 \\
\hline Imbalance in soil nutrient & 28 & 25.0 & 84 & 75.0 \\
\hline Increase in soil \& $\mathrm{H}_{2} 0$ acidity & 31 & 27.7 & 81 & 72.3 \\
\hline Increase in wind & 34 & 30.4 & 78 & 69.6 \\
\hline Increase in pest and diseases infestation & 35 & 31.3 & 77 & 68.8 \\
\hline
\end{tabular}

Source: Field Survey, 2009

Table 5. Relationship between respondents' personal characteristics and their awareness of the causes of climate change

\begin{tabular}{|l|c|c|c|c|}
\hline Personal characteristics & $\chi^{2}$ & Degree of freedom (df) & P value & Decision \\
\hline Gender & 1.17 & 1 & 0.27 & Not significant \\
\hline Age & 0.93 & 3 & 0.81 & Not significant \\
\hline Marital status & 0.64 & 1 & 0.42 & Not significant \\
\hline Educational level & 2.40 & 3 & 0.49 & Not significant \\
\hline Religion & 1.95 & 1 & 0.16 & Not significant \\
\hline Working experience & 1.87 & 3 & 0.59 & Not significant \\
\hline Area of specialization & 10.50 & 4 & 0.03 & Significant \\
\hline
\end{tabular}


Table 6. Relationship between respondents' personal characteristics and their awareness of the effect of climate change

\begin{tabular}{|l|c|c|c|c|}
\hline Personal characteristics & $\chi^{2}$ & Degree of freedom (df) & P value & Decision \\
\hline Gender & 0.01 & 1 & 0.90 & Not significant \\
\hline Age & 5.33 & 3 & 0.14 & Not significant \\
\hline Marital status & 1.29 & 1 & 0.25 & Not significant \\
\hline Educational level & 5.16 & 3 & 0.16 & Not significant \\
\hline Religion & 0.54 & 1 & 0.46 & Not significant \\
\hline Working experience & 4.42 & 3 & 0.21 & Not significant \\
\hline Areas of specialization & 12.40 & 4 & 0.01 & Significant \\
\hline
\end{tabular}

Table 7. Relationship between information sources and awareness of the causes and effect of climate change

\begin{tabular}{|c|c|c|c|}
\hline Variables & Correlation coefficient (r) & P level & Decision \\
\hline Awareness of causes of climate change & 0.32 & 0.00 & Significant \\
\hline Awareness of effects of climate change & 0.18 & 0.05 & Not significant \\
\hline
\end{tabular}

